DOI: $10.4274 /$ tjps. 49140

\title{
Essential Oil and Fatty Acid Composition of Endemic Gypsophila laricina Schreb. from Turkey
}

\author{
Hüseyin Servi, Betül Eren Keskin, Sezgin Çelik, Ümit Budak, Büşra Kababıyık \\ ${ }^{1}$ Departmant Of Pharmaceutical Botany, Faculty Of Pharmacy, Altınbas University, Istanbul, Tur ${ }^{\prime}=y$ \\ ${ }^{2}$ Department Of Molecular Biology And Genetics, Faculty Of Engineering And Natural Srien s, \\ Uskudar University, Ist; ibul, Tc 'ey \\ ${ }^{3}$ Department Of Molecuar Biology And Genetics, Faculty Of Arts \& Scier. Yildi_ aical \\ Unim--aity, , 'anbul, Turkey \\ ${ }^{4}$ Department Of Biology, Faculty Of Arts \& Science, Bozok iversit Yozgat, Turkey
}

INTRODUCTION: Gypsophila species have very 1 rh $\mathrm{m}$ u uicinal and commercial importance and also contains interesting nat ral abstances. However, there is no report on the essential oil and fatty acid, npc tion i any Gypsophila species. This prompted us to investigate the essen a... oil c $d$ fatty acid composition of Gypsophila laricina Schreb.

METHODS: Plant materials erf $c$ "ected during the flowering period. Essential oil composition of aerial $p^{2}$ is $0_{1}$ a ur ,ophila laricina Schreb. were analysed by gas chromatography and gas hromatography-mass spectrometry. And the fatty acid compositions wern anc 'sed by gas chromatography-mass spectrometry.

RESULTS. Si, v-six : Id ten compounds were identified in the essential oil and fatty acid of 3. laric na Schreb. respectively. The major components of the essential oil we he ade anoic acid (27.03\%) and hentriacontane (12.63\%). The main impou. Is of the fatty acid were (Z,Z)-9,12-octadecadienoic acid methyl ester (18: 2) 4\%, (Z)-9-octadecenoic acid methyl ester (18: 1) $35.0 \%$ and hexadecanoic a. $d$ methyl ester (16: 0) $13.0 \%$.

DISCUSSION AND CONCLUSION: The result showed that the fatty acid composition are rich in polyunsaturated fatty acids. The essential oils of $\mathrm{G}$. laricina Schreb. were dominated by fatty acid derivatives and n-alkanes. We believe the results obtained 
from this research will stimulate further research on the chemistry of Gypsophila species.

Keywords: Gypsophila laricina, essential oil, fatty acid

\section{INTRODUCTION}

Caryophyllaceae family has about 85 genera and 2630 species in the world nd distributed mainly in Mediterranean and Iran-Turan areas. ${ }^{1}$ Gypsophila is the ${ }^{\text {th }}$ biggest genus in family of Caryophyllaceae to Turkey. Gypsophila s ecies re annual, biennial or perennial herbaceous plants. Stem length of the $n$ ant,$a b c \wedge 1$ $\mathrm{m}$ and its flowering time is June and July. ${ }^{2}$

Some Gypsophila species are used in folk medicine as remt ies fo cough, cold, ailments of the upper respiratory tract $^{3}$ and also used. $r$ medical . 'atment such as expectorant, diuretic, hepatitis, gastritis and bronct is. ${ }^{4}$ ' 'e underground parts of Gypsophila genus have triterpenoid saponins a a nain component. Gypsophila genus are used in industrial, medicinal and $c \mathrm{co}^{\prime}$ ili application. ${ }^{5}$ The commercial Merck saponin which has been widely $c$.. ᄀed standard for hemolytic test was obtained from the roots of several $G$ psuphila - ecies. ${ }^{3}$ The genus were reported to have cytotoxic activity, $\alpha$-glucosi se $\varepsilon$ tivity, immune-modulating effect and normalization of carcinogen ; duc d cell proliferation. ${ }^{4,6}$ The saponins that get from Gypsophila genus are in', res $n$ te' ns of their applications in vaccines. ${ }^{7}$ Biological activities of the genu se $\mathrm{ns}$ to be associated with triterpene saponins. Due to the various beneficial bl igical activities, Gypsophila was the focus of studies that described the hytoc emıtry of the genus extensively.

Previous $a_{1}$ "oxid at and antibacterial acitivities of chloroform extracts of underg und $\mathbb{f}$ rts of Gypsophila eriocalyx and Gypsophila sphaerocephala var. $s^{r}$ la ' $c t$, ' a were investigated. The chloroform extracts of both species had high a tioxida $i$ properties but showed low antibacterial activity. ${ }^{8}$

1 'ditionaly, the toxic boron levels of some plant species (Gypsophila phaerocephala var. sphaerocephala, Gypsophila perfoliata, Puccinellia distans subsp. distans and Elymus elongates) were reported. Among these plant species, $G$. sphaerocephala contained considerably higher boron concentrations in its aboveground parts compared to the roots and organs of the other species. This study 
shows that G. sphaerocephala was not only able to grow on heavily boron contaminated soils, but was also able to accumulate extraordinarily high concentrations of boron. ${ }^{9}$

According to study from Iran, antimicrobial activity and chemical constituents of th essential oils from flower, leaf and stem of Gypsophila bicolor were investigated. he main components of the essential oil from flower were germacrene-D $\left(2^{1}, \mathrm{C}\right.$ cymene $(20.6 \%)$, bicyclogermacrene (17.6\%), p-dodecadienolacton $\left.{ }^{-1} \cdot 7 \%\right)$; ld terpinolene $(9.4 \%)$. The main components of the essential oil fro. leaves were germacrene-D (23.4\%), terpinolene $(14.5 \%)$, bicyclogerm 4 cre $>1.5 \%)$, $Y$ dodecadienolactone (6.8\%), p-cymene (6.7\%) and cis- $\beta$-ocimt $9(6.3 \%)$. The main components of the essential oil from stems were $\mathrm{Y}-\mathrm{L}$ decadieno, tone $(28.5 \%)$, bicyclogermacrene (14.8\%), germacrene-D (1: $6 \%$, p-cymene $(12.5 \%)$, terpinolene $(11.6 \%)$ and trans- $\beta$-ocimene $(4.2 \% 1$. ᄀ es ential oils had moderate effect on Gram-positive and Gram negative b cte $a$, "ut had significant effect on the fungi. ${ }^{10}$

Another study from Turkey, esser sal oil position and fatty acid profile of Gypsophila tuberculosa and Gyp sphile eriocalyx were reported. The main components of essential oi', wr e determined hexadecanoic acid (25.3\%) and hentriacontane $(13.0 \%)$ or tur srculosa and octacosane $(6.83 \%)$, eicosanal $(6.19 \%)$, triacontane 0.0 ' ) and heneicosane $(5.78 \%)$ for G. eriocalyx. The major compounds of fattv ac 's of $G$. tuberculosa and $G$. eriocalyx were (Z)-9-octadecenoic acid methyl ster ( $? .0 \%, 36.0 \%),(Z, Z)-9,12$-octadecadienoic acid methyl ester (19.6\%, 1 - $-\%$, and ' exadecanoic acid methyl ester (17.7\%, 25.2\%), respectively. ${ }^{11}$

As sum narizec above Gypsophila species have very high medicinal and commercial in so. ncu d also contains interesting natural substances. However, according to i litera.ure survey we have not encountered any reports on the essential oil and 'atty cid composition of Gypsophila laricina Schreb. This prompted us to investigate $t^{\prime} \in$ essential oil and fatty acid composition of Gypsophila laricina Schreb. Here we report for the first time on the essential oil composition and fatty acid profile of Gypsophila laricina Schreb.

\section{EXPERIMENTAL}




\section{Plant Materials}

Plant materials were collected during the flowering period; Gypsophila laricina Schreb. was collected from 1740 m-1800 m height in Ucpinar, Sarkisla, Sivas, Turkey in July 2015 by Celik and Budak. Voucher specimen has been deposited in the Herbarium of Bozok University (Voucher no. Bozok HB 3302).

\section{Fatty Acids Analyses}

The aerial parts of the collected specimen, dried separately in shadow a ad grc nd with an electric mill (Retsch SM 100). Aerial part of the plant (400 g) Nas vtrar ed with hexane for three days at room temperature. After filtration thrnigh filter paper, the extract was concentrated by rotary evaporator and $4 \mathrm{~g}$ cruc $\cdot$ hexal extract were obtained from the aerial parts of Gypsophila laricina Tchreb. The ar e extract was stored at $4^{\circ} \mathrm{C}$. In this study we used hexane extra $-r$ fatty acl compositions. Methyl-ester derivatives of fatty acids (FAME), founc in hex . ₹ extract was obtained by transesterification method. ${ }^{11}$ In this metho 10 . Jritu $E x$ tract was dissolved in 5 $\mathrm{mL}$ hexane and then extracted with $2 \mathrm{~N} r$ atl olic $\mathrm{OH}$ at room temperature. The mixture was shaken for $2 \mathrm{~min}$ and allnwed 'o stand for $10 \mathrm{~min}$. The upper phases were removed. G. laricina Schreb. affordc $y$ fixed oil from the hexane extract with $0.07 \%(\mathrm{v} / \mathrm{w})$ yields. The fixed $c^{\prime \prime}<\mathrm{a} .1 \mathrm{~s}$ ed by GC-MS system.

\section{Essential Oils Analyses}

Aerial parts $(200 \mathrm{~g})$ the a dried plants subjected to hydrodistillation for $3 \mathrm{~h}$, using a Clevenger-tyr vá. tus to produce essential oils. Condenser of the Clevenger was attached $\rho$ a $\mathrm{mi}$ rochiller that set to $4^{\circ} \mathrm{C}$. G. laricina Schreb. afforded oils from the aeri , parts w.... $0.01 \%(\mathrm{v} / \mathrm{w})$ yields. The oils were recovered with $1 \mathrm{~mL} n$-hexane and nre: rved 1 amber vials under $-20^{\circ} \mathrm{C}$ until the day they were analysed.

- 's chrc. iatography/mass spectrometry for fatty acids

Q fatty acid compositions of the hexane extracts were investigated by means of sas Chromatography-Mass Spectroscopy (GC-MS) system. The fatty acid methyl esters were analyzed using Agilent 5975C GC-MSD system with Innowax FSC polar column $(30 \mathrm{~m} \times 0.25 \mathrm{~mm}, 0.25 \mu \mathrm{m})$. The inlet temperature was set at $250^{\circ} \mathrm{C}$. Helium was the carrier gas at a constant flow rate of $1 \mathrm{ml} / \mathrm{min}$. Split ratio was set to $50: 1$. The 
oven temperature was programmed from $40^{\circ} \mathrm{C}$ to $210^{\circ} \mathrm{C}$ at rate of $5^{\circ} \mathrm{C} / \mathrm{min}$ and kept constant at $210^{\circ} \mathrm{C}$ for $10 \mathrm{~min}$. El/MS was taken at $70 \mathrm{eV}$ ionization energy. Mass range was from $\mathrm{m} / \mathrm{z}$ 35-450 amu (atomic mass unit). Relative percentage amounts of the separated compounds were calculated from integration of the peaks in MS chromatograms. Identification of fatty acid components were carried out by comparison of their retention indices (RI) obtained by series of $n$-alkanes (C5 to C? ${ }^{r}$ to the literature and with mass spectra comparison. ${ }^{13-19}$ Mass spectra compar on was done by computer matching with commercial Wiley 8th Ed./NIST Jo "as. Spectra library. Analysis was completed in 50 minutes.

\section{Gas Chromatography/Mass Spectrometry for essential oils}

The GC-MS analysis was performed with an Ag. nt 5975C - C-MSD system operating in El mode. Essential oil samples were di cteu 1/100 (v/v) with $n$-hexane. Injector and MS transfer line temperatures were set $+250^{\circ}$,. Innowax FSC column (60 m x $0.25 \mathrm{~mm}, 0.25 \mu \mathrm{m}$ film thickness) nd slium as carrier gas $(1 \mathrm{~mL} / \mathrm{min}$ ) were used in both GC/MS analyses. 'plit. is ir ection was employed. Oven temperature was programmed to $60^{\circ}$ cor 7 min. and raised to $220^{\circ} \mathrm{C}$ at rate of $4^{\circ} \mathrm{C} / \mathrm{min}$. Temperature kept constan at 220 ; for $10 \mathrm{~min}$. and then raised to $240^{\circ} \mathrm{C}$ at a rate of $1^{\circ} \mathrm{C} / \mathrm{min}$. Mass spect $\sim \mathrm{w}$. $\mathrm{N}$ ded at $70 \mathrm{eV}$ with the mass range $\mathrm{m} / \mathrm{z} 35$ to 425 .

\section{Gas Chromatograph» ror $\epsilon$. - ential oils}

The GC anal ses 'er done with an Agilent 6890N GC system. FID detector temperature $\mathrm{n}$ s set, $300^{\circ} \mathrm{C}$ and same operational conditions applied to a duplicate of the $s$ me col'umın used in GC-MS analyses. Simultaneous auto injection was done to tair he ame retention times. Relative percentage amounts of the separated impou. Is were calculated from integration of the peaks in FID chromatograms. Ide, ification of essential oil components were carried out by comparison of their $r$ tive retention indices (RRI) obtained by series of $n$-alkanes (C5 to C30) to the iterature and with mass spectra comparison. ${ }^{20-40}$ Mass spectra comparison was done by computer matching with commercial Wiley 8th Ed./NIST 05 Mass Spectra library, Adams Essential Oil Mass Spectral Library and Pallisade 600K Complete Mass Spectra Library. 


\section{RESULT AND DISCUSSION}

Fatty acid composition of Gypsophila laricina Schreb. were analysed by GC-MS. Ten compounds were identified in the fatty acid that represent $98.9 \%$ of the fatty acid. The extract consisted of six saturated fatty acids $(21.8 \%)$ and four unsaturated fatty acids $(77.2 \%)$. The major components of the fatty acid were $(Z, Z)-9,12$ octadecadienoic acid methyl ester (Linoleic acid) (18:2) 40.4\%, (Z)-9-octadece' Jic acid methyl ester (Oleic acid) (18:1) 35.0\% and hexadecanoic acid methvl e. ar (Palmitic acid) (16:0) $13.0 \%$. The fatty acid composition of Gypsoph a lark na Schreb. are represented in Table 1.

Essential oil composition of Gypsophila laricina Schreb. were naly ?d, GC and GC-MS. The essential oils of aerial parts of Gypsophila laricina - threb afforded very low oils yields $0.03 \%(\mathrm{v} / \mathrm{w})$ yield). Sixty-six compounds are identific in the essential oil of $G$. laricina Schreb. by GC system that repres nt $7 t>\%$ of the oil. The major components of the oil were hexadecanoic mid $57.0 \%$ ) and hentriacontane $(12.63 \%)$. The essential oil composition of $G$ ps sh' 7 laricina Schreb. are given in Table 2.

The essential oil composition of Gypsc hila laricina showed similar chemical behaviour to $G$. tuberculos it th species had hexadecanoic acid and hentriacontane as major $\mathrm{c} \mathrm{nr}^{\mathrm{u}}$ une ts in essential oils. But hexadecanoic acid contained at $4.64 \%$ i $t$ is in eriocalyx and in a nearly six amount in $G$. tuberculosa and $G$. ricina. 'nd also hentriacontane contained at very low amounts in G. eriocalyx ${ }^{1}$, ret -ypsophila species had linoleic acid, oleic acid and palmitic acid as main ( Impon nts in different percentage in fatty acids.

Accordi $g$ to study from Iran, Gypsophila bicolor was reported to contain g . . r. re $1 ., p$-cymene, bicyclogermacrene, $y$-dodecadienolactone, terpinolene, $\therefore-\beta$-ocli ene and trans- $\beta$-ocimene ${ }^{10}$ however these compounds were not detected , th oil of Gypsophila laricina Schreb. Gypsophila laricina Schreb. showed very $c$ hierent chemical behaviour from $G$. bicolor. These differences in the previous literature and present data could be related to different collection times, climatic and soil conditions, ecological factors, methods and instruments employed in analysis or different genotypes. There are very few reports on the essential oil or volatile composition of Gypsophila species therefore it is difficult to produce a comment on 
the chemo-systematic position of this species according to current findings and the existing reports.

\section{CONCLUSION}

The essential oil composition and fatty acid profile of G. laricina Schreb. are investigated for the first time. The major components of the fatty acid were oleic a $\gamma$, linoleic acid and palmitic acid. The unsaturated fatty acids content were $r$ gher $\mathrm{t}$ an their saturated fatty acids content. The essential oils of G. laricina sch. h. v sre dominated by fatty acid derivatives and $n$-alkanes. Hexadonanc acid and hentriacontane are found as major components in es atial i. The high hexadecanoic acid content might be explained $a b c$ 't the collt in time of plant materials at late flowering period. Gypsophila laricina hited impo nt differences Gypsophila bicolor and Gypsophila eriocalyx highlis hting $\mathrm{t}$ existence of different main chemical constituents. Thus, the results thls stuu, certainly contributed to the taxonomy of the genus Gypsophila via c c'nt. ' vil ct zmistry. We believe the results obtained from this research will stimulate further research on the chemistry of Gypsophila species.

\section{ACKNOWLEDGEMENTS}

We are indebted to YTL $3 A P$ _ 111T820) for the fin cial si nort.

\section{REFERENCE}

1. $N$ abberle $y$ J. Mabberley's plant-book: a portable dictionary of plants, their ( 7ssific ions, and uses (3th ed). Cambridge; Cambridge University Press; $202.1,0$.

2. L vis $\mathrm{PH}$, Mill RR, Tan $\mathrm{K}$ and Edmondson JR. Flora of Turkey and the East Aegean Islands (2nd ed). Edinburgh; University Press; 1982:2;149-180.

3. Elbandy M. Miyamoto T. \& Lacaille-Dubois MA. Sulfated lupane triterpene derivatives and a flavone C-glycoside from Gypsophila repens. Chem Pharm Bull. 2007;55:808-811.

4. Yücekutlu AN. \& Bildacı I. Determination of Plant Saponins and Some of Gypsophila Species: A review of the literature. Hacettepe J Biol Chem. 2008;36:129-135. 
5. Krasteva IN. Popov IS. Balabanova VI. Nikolov SD. \& Pencheva IP. Phytochemical study of Gypsophila trichotoma wend (Caryophyllaceae). Quim Nova. 2008;31:1125-1126

6. Xie LX. Zhang HC. Wang HY. Wang Y. Wang FL. \& Sun JY. Two new triterpenoids from Gypsophila oldhamiana. Nat Prod Res. 2016;30:1068-1074.

7. Gevrenova R. Stancheva T. Voynikov Y. Laurain-Mattar D. \& Henry M. Root in vitro cultures of six Gypsophila species and their saponin contents. Enzyme Microb Tech. 2010;47:97-104.

8. Çona IG. Gypsophila eriocalyx Boiss. ve G. sphaerocephala Fenzl ex tch lat var. sphaerocephala taksonlarının antioksidan ve antibakteriyel akti ... rir. belirlenmesi. Master thesis. Pamukkale University. 2012.

9. Babaoglu M. Gezgin S. Topal A. Sade B. \& Dural H. G, רon illa sphaerocephala Fenzl ex Tchihat.: a boron hyperaccumulato lant species that may phytoremediate soils with toxic B levels. Turk $\sim+24$ < $28: 273-$ 278.

10. Shafagha A. Shafaghatlonbar M. Antimic bbial acti and chemical constituents of the essential oils from flower, if and ste, of Gypsophila bicolor from Iran. Nat Prod Commun. 2011;6:2 $0-2$ i

11. Servi H. Keskin BE. Celik S. Budak U. K mizite 3 FC. and Bektas EB. Essential oil composition and fatty ac, $\mathrm{p}_{1}$, ile - Iwo endemic Gypsophila species from Turkey. Am J Essert Oil I at ' Ioc $^{\prime} 2017 ; 5: 16-20$

12. PaquoT C. Standard Methods fo,$A_{1}$ is of Oils, Fats and Derivatives (6th ed). Oxford;Pergamon Pre -20 , 16:1-188.

13. Eyol PC. Sarikahya NB. Ka 'koc C :. Gokce A. Demirci F. Kirmizigul S. \& Goren N. Fatty Acid C-mpc tion and Biological Activities of Tanacetum zahlbruckneri (Náb.) G iers ' I Growing in Turkey. Rec Nat Prod. 2017;11:401405.

14. Kirmizigul S. Sá 'ahya ivB. Sümbül H. Arda N. Essential fatty acid components : nd a. 'ioxidant activities of eight Cephalaria species from southwestern r atolia. Pure Appl Chem. 2007;79:2297-2304.

15. Maltas $\therefore$. Vu ' $\mathrm{C}$... Yildiz S. Antioxidant acvitiy and fatty acid composition of Ginkqc viloba om Turkey. Pure Appl Chem. 2011;35:803-818.

16.I rribi B ruuki K. Mougou A. Marzouk B. Fatty acid and essential oil c mposi on of three Tunisian caraway (Carum carvi L.) seed ecotypes. J Sci Fo ' sr. 2010;90:391-396.

17. D. is C. Wielgosz-Collin G. Bretéché A. Ruiz N. Rabesaotra V. Boury-Esnault N. Kornprobst JM. Barnathan G. New 17-Methyl-13-Octadecenoic and 3,16Docosadienoic Acids from the Sponge Polymastia penicillus. Lipids. 2009; 44:655-663.

18. Tsevegsuren N. Fujimoto K. Christie WW. Endo Y. Occurrence of a Novel cis,cis,cis-Octadeca-3,9,12-trienoic (Z,Z,Z-octadeca-3,9,12,trienoic) Acid in Chrysanthemum (Tanacetum) zawadskii Herb. (Compositae) Seed Oil. Lipids. 2003;38:573-578. 
19. Nickavar B. Mojab F. Javidnia K. Amoli MA. Chemical Composition of the Fixed and Volatile Oils of Nigella sativa L. from Iran. Z Naturforsch C. 2003;58:629-631.

20. Polatoğlu K. Şen A. Bulut G. Bitiş L. Gören N. Essential Oil Composition of Centaurea stenolepis Kerner. from Turkey. J Essent Oil Bear PI. 2014;17:1268-1278.

21. Polatoğlu K. Arsal S. Demirci B. Başer KH. DPPH Scavenging, PRAP Activities and Essential Oil Composition of Edible Lathyrus ochrus L. (Cyp is Vetch, Luvana) from Cyprus. J Oleo Sci. 2015;64:309-314.

22. Polatoğlu K. Demirci F. Demirci B. Gören N. Başer KHC. Antibacteri . . +iv. and the Variation of Tanacetum parthenium (L.) Schultz Bip. Es: zntial ils from Turkey. J Oleo Scl. 2010;59:177-184.

23. Polatoğlu K. Demirci B. Gören N. Başer KHC. Essential oil L mposition of Tanacetum kotschyi from Turkey. Chem Nat Compd. 2011,+r. '97-. 99.

24. Polatoğlu K. Gören N. Karakoç ÖC. Phytotoxic, DPPH sı vengii y, insecticidal

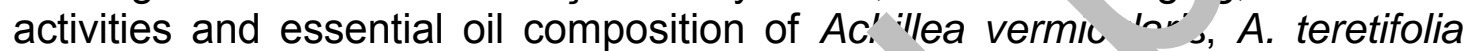
and proposed chemotypes of $A$. biebersteinii (. steraceae). 'nd Crop Prod. 2013;51:35-45.

25. Polatoğlu K. Karakoç ÖC. Yücel YY. [ mirci B. Gören N. Başer $\mathrm{KH}$. Composition, insecticidal activity an On.. biological activities of Tanacetum abrotanifolium Druce esse tia' vil. ' dd Crop Prod. 2015;71:7-14.

26. Polatoğlu K. Demirci B. Demirci F örel. ' uşer KH. Biological activity and essential oil composition of tw ...w, nacetum chiliophyllum (Fisch. \& Mey.) Schultz Bip. var. chiliophyllur chem types from Turkey. Ind Crop Prod. 2012; 39:97-105.

27. Sura BE. Demirci B. Jer . S. Karaalp C. Başer KH. Composition of the essential oils of Cf tá $r$ a ar irodisea, C. polyclada, C. athoa, C. hyalolepis and C. iberica. J sent 1 r us. 2013;25:79-84.

28. Karamenderf $<$ C. D virci B. Başer KH. Composition of Essential Oils of Ten Centaurea L. I va frorı Turkey. J Essent Oil Res. 2008;20:342-349.

29. Demirc B. Bc er .H. Yıldız B. Bahçecioğlu Z. Composition of the essential oils of $:<$ ende lic Salvia spp. from Turkey. Flavour Frag J. 2003;18:116-121.

30.1 oronkola uU. Ogunwande IA. Başer KHC. Ozek T. Ozek G. Essential Oil ( Impos ion of Gmelina arborea Roxb., Verbenaceae from Nigeria. J Essent Oı ... 2009;21:264-266.

31. B. sole IHN. Ouattara AS. Nebie R. Ouattara CAT. Kabore ZI. Traore SA. Chemical composition and antibacterial activities of the essential oil of Lippia chevalieri and Lippia multiflora from Burkina Faso. Phytochemistry, 2003;62: 209-212.

32. Kose YB. Altintas A. Tugay O. Uysal T. Demirci B. Ertugrul K. Baser KHC. Composition of the Essential Oils of Centaurea sericeae Wagenitz and Centaurea ensiformis P.H. Davis from Turkey. Asian J Chem. 2010;22:71597163. 
33. Kirimer N. Tabanca N. Özek T. Tümen G. Baser KHC. Essential oils of Annual Sideritis Species Growing in Turkey. Pharm Biol. 2000;38:106-111.

34. Saidana D. Mahjoub MA. Boussaada O. Chriaa J. Cheraif I. Daami M. Mighri Z. Helal AN. Chemical composition and antimicrobial activity of volatile compounds of Tamarix boveana (Tamaricaceae). Microbiol Res. 2008;163:445-455.

35. Bardakcı H. Demirci B. Yesilada E. Kirmizipekmez H. Baser KHC. Chemical Composition of the Essential Oil of the Subterranean Parts of Valeri- ra alliariifolia. Rec Nat Prod. 2012;6:89-92.

36. Tabanca N. Demirci B. Ozek T. Kirimer N. Baser KHC. Bedir E. Wedge DE. Gas chromatographic-mass spectrometric analysis $c$ esse, ial oils from Pimpinella species gathered from Central and Nortr in rurke $\mathrm{J}$ Chromatogr A, 2006;1117:194-205.

37. Polatoglu K. Demirci F. Demirci B. Gören N. Baser KHC Nir. icr vial activity and Essential oil composition of a new T. argyrophyllu (C.Kc h) T'vzel. var. argyrophyllum chemotype. J Oleo Sci. 2010;59·307-313.

38. Dregus M. Engel KH. Volatile constituents ol ncooked, ibarb (Rheum rhabarbarum L.) stalks. J Agr Food Chem. 200 ; 51: \30-6536.

39. Miyazawa M. Nagai S. \& Oshima T. Volatile Com onents of the Straw of Oryza sativa L. J Oleo Sci. 2008;57:13? 143

40. Viegas MC. \& Bassoli DG. Ut "̧̧ã to í dice de retenção linear para caracterização de compostos vora. is $e_{1}$. afé solúvel utilizando GC-MS e coluna HP-Innowax. Quím No' .. . .00, 'n? 2031-2034. 
Table 1. The fatty acid composition of Gypsophila laricina Schreb.

\begin{tabular}{|c|c|c|c|}
\hline $\mathbf{R I}^{\mathbf{1}}$ & Compound & Mean(\%) & Id. Met. $^{3}$ \\
\hline 1299 & Dodecanoic Acid ME (Lauric acid) & 0.3 & $\mathrm{RI}, \mathrm{MS}$ \\
\hline 1499 & Tetradecanoic Acid ME (Myristic acid) & 1.2 & $\overline{\mathrm{I}, \mathrm{MS}}$ \\
\hline 1678 & (Z)-9-Hexadecenoic Acid ME* (Palmitoleic acid) & 0.6 & $\mathrm{RI}, \mathrm{MS}$ \\
\hline 1699 & Hexadecanoic Acid ME (Palmitic acid) & 10 & RI, MS \\
\hline 1867 & $\begin{array}{l}\text { (Z,Z)-9,12-Octadecadienoic Acid } \\
\text { acid) }\end{array}$ & 40.4 & $\mathrm{RI}, \mathrm{MS}$ \\
\hline 1873 & $\overline{(Z)-9-O c t a d e c e n o i c ~ A c i d ~ M E * ~(O l e i ~} \overline{a^{\prime}}{ }_{\lambda}$ ) & 35.0 & RI, MS \\
\hline 1899 & Octadecanoic Acid ME (Ste & 2.3 & RI, MS \\
\hline 1984 & $\overline{(Z)-11-E i c o s e n o i c ~ A c i d ~}{ }^{\prime} L \overline{' G o n '} \overline{\text { jic acid) }}$ & 1.2 & RI, MS \\
\hline 1999 & $\overline{\text { Eicosanoic Acir M }} \bar{V}_{\text {sac }} \overline{\text { dic acid) }}$ & 3.4 & RI, MS \\
\hline \multirow[t]{5}{*}{2299} & $\overline{\text { Docosanni }}, \overline{A c l c}$ 'ME (Behenic acid) & 1.5 & RI, MS \\
\hline & Tot sa, rat y acid & 21.8 & \\
\hline & ota. aturated acid & 77.2 & \\
\hline & $\overline{T_{n+t}}$ & 98.9 & \\
\hline & Unsaturated/saturated & 3.6 & \\
\hline
\end{tabular}

* atty acids with cis (Z) configuration, ME: Methyl ester,

${ }^{1} \mathrm{RI}$ : Retention indices,

${ }^{2}$ The results of the analysis, 
3Identification method: RI: identification based on the retention times (RI) of genuine compounds on the HP Innowax column and the literature data; MS: identification based on MS comparison with the database or the literature data.

Table 2. The essential oil composition of Gypsophila laricina Schreb.

\begin{tabular}{|c|c|c|c|c|c|c|}
\hline No & RRI' & RRI Lit. ${ }^{2}$ & Compound & $\begin{array}{l}\text { Mean } \\
(\%)^{3}\end{array}$ & Id. Met. ${ }^{4}$ & Lit. $^{5}$ \\
\hline 1 & 1233 & 1244 & 2-pentyl furan & 0.27 & RI, MS & \\
\hline 2 & 1397 & 1399 & Nonanal & 0.29 & RI, MS & \\
\hline 3 & 1400 & 1400 & Tetradecane & 0.16 & $\mathrm{RI}$, 'S, Ac & \\
\hline 4 & 1442 & 1443 & $\begin{array}{l}\text { Dimethyl- } \\
\text { tetradecane }\end{array}$ & $0.6=$ & RI, MS & 27 \\
\hline 5 & 1499 & 1505 & Dihydroedulan II & $0 \cdot 5$ & ' MS & 27 \\
\hline 6 & 1502 & 1500 & Pentadecane & & RI, MS, Ac & \\
\hline 7 & 1504 & 1505 & Decanal & & RI, MS & 28 \\
\hline 8 & 1510 & 1516 & $\mathrm{~B}$ & 0.7 & $\mathrm{RI}, \mathrm{MS}$ & 28 \\
\hline 9 & 1525 & 1532 & & 0.04 & $\mathrm{RI}, \mathrm{MS}$ & 22 \\
\hline 10 & 1529 & 1535 & D. droe ulan I & 0.14 & RI, MS & 28 \\
\hline 11 & 1543 & & 'E)-2-nonenal & 0.12 & RI, MS & 28 \\
\hline 12 & 1549 & & Theaspirane A & 0.64 & RI, MS & 27 \\
\hline 13 & 15,8 & 154 & 1-Tetradecene & 0.08 & RI, MS & 28 \\
\hline 4 & 60 & 1600 & Hexadecane & 0.29 & RI, MS, Ac & \\
\hline 15 & 162 & 1638 & $\beta$-cyclocitral & 0.13 & RI, MS & 28 \\
\hline 16 & 1635 & 1644 & Thujopsene & 0.04 & RI, MS & 32 \\
\hline 17 & 1652 & 1655 & (E)-2-decanal & 0.25 & RI, MS & 28 \\
\hline 18 & 1660 & 1664 & Nonanol & 0.1 & RI, MS & 28 \\
\hline 19 & 1693 & 1685 & $\begin{array}{l}\text { 6,10-dimethyl-2- } \\
\text { undecanone }\end{array}$ & 0.1 & RI, MS & 39 \\
\hline 20 & 1702 & 1700 & Heptadecane & 0.28 & RI, MS, Ac & \\
\hline
\end{tabular}




\begin{tabular}{|l|l|l|l|c|l|c|}
\hline 21 & 1717 & 1722 & Dodecanal & 0.29 & RI, MS & 28 \\
\hline 22 & 1761 & 1763 & Naphthalene & 0.32 & RI, MS & 28 \\
\hline 23 & 1775 & 1779 & $\begin{array}{l}\text { (E,Z)-2,4- } \\
\text { Decadienal }\end{array}$ & 0.13 & RI, MS & 28 \\
\hline 24 & 1804 & 1779 & Octadecane & 0.21 & RI, MS, Ac & \\
\hline
\end{tabular}

Table 2. Continued

\begin{tabular}{|c|c|c|c|c|c|c|}
\hline No & RRI $^{1}$ & $\begin{array}{l}\text { RRI } \\
\text { Lit. }^{2}\end{array}$ & Compound & $\begin{array}{l}\text { Mean } \\
(\%)^{3}\end{array}$ & Id. Met. ${ }^{4}$ & Lit. $^{5}$ \\
\hline 25 & 1824 & 1827 & $(E, E)-2,4$-decadienal & 0.4 & RI, MS & \\
\hline 26 & 1831 & 1823 & 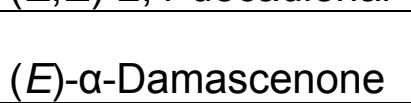 & 0.2 & RI, MS & \\
\hline 27 & 1836 & 1838 & $(E)-\beta$-Damascenone & 0.36 & RI & \\
\hline 28 & 1865 & 1864 & (E)-Geranyl acetone & & 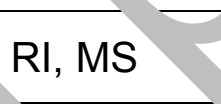 & \\
\hline 29 & 1879 & 1871 & Undecanol & $C_{17}$ & $1 M S$ & 33 \\
\hline 30 & 1886 & 1864 & $p$-Cymє & & ואז, MS & 28 \\
\hline 31 & 1931 & 1933 & & & RI, MS & 28 \\
\hline 32 & 1953 & 1958 & $(E)-\beta-I$ & 1.03 & RI, MS & 28 \\
\hline 33 & 1968 & 1973 & & 0.63 & RI, MS & 28 \\
\hline 34 & 2002 & & & 0.29 & RI, MS, Ac & \\
\hline 35 & 2005 & & & 0.29 & RI, MS & 23 \\
\hline 36 & 2037 & & Pentadecanal & 0.26 & RI, MS & 21 \\
\hline 37 & $\overline{043}$ & 250 & $(E)$-Nerolidol & 0.05 & RI, MS & 24 \\
\hline 38 & 20 & 2056 & 13-Tetradecanolide & 0.35 & RI, MS & 37 \\
\hline 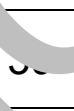 & $\sqrt{35}$ & 2131 & $\begin{array}{l}\text { Hexahydro farnesyl } \\
\text { acetone }\end{array}$ & 1.65 & RI, MS & 21 \\
\hline 40 & 2138 & 2142 & Spathulenol & 0.05 & RI, MS & 20 \\
\hline 41 & 2145 & 2136 & Hexadecanal & 0.3 & RI, MS & 27 \\
\hline 42 & 2170 & 2192 & Nonanoic acid & 0.5 & RI, MS & 22 \\
\hline 43 & 2276 & 2282 & Decanoic acid & 1.03 & RI, MS & 20 \\
\hline 44 & 2304 & 2300 & Tricosane & 0.55 & $\mathrm{RI}, \mathrm{MS}, \mathrm{Ac}$ & \\
\hline
\end{tabular}




\begin{tabular}{|c|c|l|l|c|l|c|}
445 & 2315 & 2315 & $\begin{array}{l}\text { 2,4-bis(tert- } \\
\text { butyl)phenol }\end{array}$ & 0.35 & RI, MS & 40 \\
\hline 46 & 2354 & 2353 & Octadecanal & 0.28 & RI, MS & 36 \\
\hline 47 & 2382 & 2384 & Farnesyl acetone & 1.41 & RI, MS & 20 \\
\hline 48 & 2407 & 2400 & Tetracosane & 0.31 & RI, MS, Ac & \\
\hline
\end{tabular}

Table 2. Continued

\begin{tabular}{|c|c|c|c|c|c|c|}
\hline No & $\mathbf{R R}^{1}$ & $\begin{array}{l}\text { RRI } \\
\text { Lit. }^{2}\end{array}$ & Compound & $\begin{array}{l}\text { Mean } \\
(\%)^{3}\end{array}$ & Id. Met. ${ }^{4}$ & Lit. $^{5}$ \\
\hline 49 & 2448 & 2471 & Nonadecanal & 0.2 & RI, MS & \\
\hline 50 & 2488 & 2492 & Dodecanoic acid & 3.51 & RI, MS & \\
\hline 51 & 2508 & 2500 & Pentacosane & 1.4 & RI, i,,$A c$ & \\
\hline 52 & 2585 & 2582 & Eicosanal & & RI, $\mathrm{N}$ & \\
\hline 53 & 2590 & 2617 & Tridecanoic acid & & h MS & 28 \\
\hline 54 & 2606 & 2600 & Hexacosane & & રા. & \\
\hline 55 & 2615 & 2614 & Phytol & & RI, MS & 20 \\
\hline 56 & 2671 & 2676 & Heneico anal & 1.97 & RI, MS & 30 \\
\hline 57 & 2701 & 2704 & Tf au arı... acid & 4.7 & RI, MS & 21 \\
\hline 58 & 2708 & 2700 & $H_{t}$ aco $\lambda$ ne & 0.7 & RI, MS, Ac & \\
\hline 59 & 2775 & 83 & Docosanol & 0.31 & RI, MS & 30 \\
\hline 60 & 2795 & 8 & Octacosane & 0.25 & $\mathrm{RI}, \mathrm{MS}, \mathrm{Ac}$ & \\
\hline 61 & 803 & 2,09 & Pentadecanoic acid & 1.4 & $\mathrm{RI}, \mathrm{MS}$ & 20 \\
\hline 62 & & 2857 & Palmito-y-lactone & 0.21 & RI, MS & 37 \\
\hline 6 & 321 & 2931 & Hexadecanoic acid & 27.03 & RI, MS & 25 \\
\hline 64 & 2982 & 2990 & Docosanal & 0.22 & RI, MS & 30 \\
\hline 65 & 3108 & 3100 & Hentriacontane & 12.63 & RI, MS, Ac & \\
\hline & & & Total & 76.0 & & \\
\hline
\end{tabular}

In addition to the above data, diisobutyl phthalate is a common plasticizer contaminant and it was detected as a considerable component as 2.15 percentage for $G$. laricina Schreb.

${ }^{1} \mathrm{RRI}$ (FID): Relative retention time indices calculated against $n$-alkanes (C5-C30) in FID chromatograms ${ }^{2}$ RRI Lit.: Relative retention time given in the literature for the compound in similar columns and analysis conditions. 
${ }^{3}$ The result of the analysis in FID chromatograms.

${ }^{4}$ Identification method: RI: identification based on the relative retention times (RRI) of genuine compounds on the HP Innowax column and the literature data; MS: identification based on MS comparison with the database or the literature data, Ac: Identification is done according to RRI and MS values of the authentic compounds.

Lit.5: Literature 